\title{
Capitalism, CRF and the Hypocrisy in Achieving Social Class Leaping by Diligence Only
}

\author{
Yuan Fang \\ Chinese University of Hong Kong, Hong Kong, China
}

\begin{abstract}
In recent years there has been a widely spread unemployment disparities throughout the United State, though in 2019 unemployment rate fell to 3.5\%, with COVID-19 continue to sweeping the continent in 2020, unemployment rate raised back to $6.7 \%$ by November 2020 with a raise in non-farm payroll employment of 245,000 in November alone (Bureau of Labor Statistics). At the moment, an increasing number of recent college graduates are having a more difficult time finding a good job than before. While the public now is starting to promote training schools for high school graduates instead of college for alternative, Joshua David Hawley (born December 31, 1979) who is the son of a banker and a teacher defeated Kurt Schaefer in the Republican primary with $64 \%$ of the vote in 2016 in the attorney general race is now serving as the youngest current U.S. senator after defeating two-term Democratic incumbent Senator Claire McCaskill in the 2018 election(Austin). In this paper, we explored this issue of inequality of social class differences by examine the formation and solidification of the capitalist class while studying foundation of the CFR (Council of Foreign Relation), we have find that in present day a predictable outcome for a college student is now no longer involving a guaranteed change in their livelihood, and achieving social class leaping by diligence only has turning into nothing but a hypocrisy.
\end{abstract}

Keywords: Capitalism, CRF, Social Class Leaping, inequality

\section{Capitalist Class and its Origin}

Capitalism is an economic term used to explain the concept of private ownership of the means of production, by maintaining such ownership the owners can gain profits from their operation. According to Marxian class theory, any individual's position within the society is determined by their role in the production process, and he argued that for all people, their political and ideological consciousness is also determined by their very own class position. In his theory, Marx distinguishes one class from another based on two different categories : ownership of the means of production and control over others in labor power. Capitalists are the ones owning the means of production and can purchase the labor power though financial and other material means, working class on the opposites sells their time and labor for a small portion of the profit as benefits in return.

For the capitalist class, their interest is to maximize their profit at the expense of their labors wages and benefits, while the labors interest is the exact opposite, though most of the 
time the laborers and capitalists themselves might not even be aware of such clash of interest during their daily operations.

\section{Employment Outcome Among Different Social Classes}

Many researches has shown that there is a long standing distinctive advantage a social class position can promote in protecting an individual from unemployment, and the relationship between an individual's innate social class has continue to develop after the turn of the millennium. A research done by researchers from University of Helsinki using a register-based data collection on the Finnish labour force over a 28-year period between 1988 and 2015 has shown that risk of unemployment falls in between 2.7-3.7\% among working class compared to a $1.4-1.7 \%$ for the upper non-manual class people. There is a small distinction between genders also, but such differences is continue to narrow over time and is relatively small (shown in Figure.1) in contrast to the differences in between different social classes. (Lahtinen)

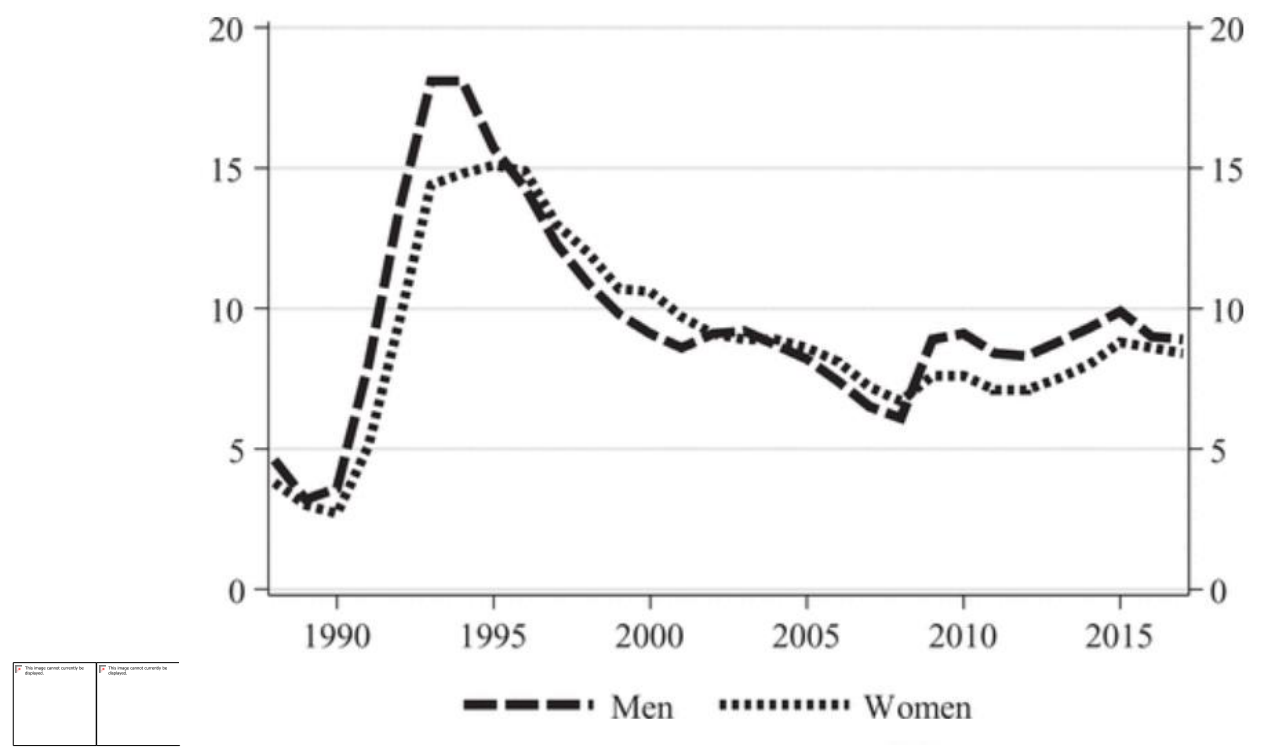

Figure 1. Unemployment Rate From 1988 to 2017 in Finland by gender (\%).

Moreover, comparing to the decline we see in employment rate differences between genders, social stratification and in unemployment remind constant considerably persistent through out the years. Overall, capitalists and upper classes remind their advantage when comes to securing jobs and avoiding being laid off during hard economic periods.

\section{Council on Foreign Relations}

\subsection{History and background Council on Foreign Relations}

The Council on Foreign Relations was founded in 1921 when 150 scholars got called to 
advice President Woodrow Wilson regarding the options the United States have for the postwar world strategies when Germany was defeated at end of the world war I, the meeting resulted in over 2000 document covering all aspects of post war strategies ranging from political, economical, social effect and others, the group then traveled to he Paris Peace Conference 1919 to participated in such discussion. As the result of this conference, a small group of British and American diplomats gathered and formed an alliance called the "The Institute of International Affairs", they set up offices in both London and New York for future advisory purpose. Later on the British broke apart from the organization and created the Royal Institute of International Affairs (or Chatham House in present day term) in London, and the left behind Americans became the present day Council for Foreign Relation.

Right now the CRF is a nonprofit think tank specializing in U.S. foreign policy and international affairs. Its headquartered remind in New York City and the organization also set up additional office in Washington, D.C. Currently there are 5,103 members residing within the organization. Term membership is available for those between the ages of 30 and 36 only and life membership needs to go through a series of nomination process. CFR members came from various background including high ranking government officials such as senior politicians, the secretaries of state CIA directors, also there are bankers, lawyers and academic scholars too.

\subsection{Why is Council on Foreign Relation important}

According to the book "Wall Street's Think Tank",CFR is now considered the world's most powerful private organization. This organization is the ultimate networking, socializing, strategic-planning, and consensus forming institution of the U.S. capitalist class. The CFR is the like the invisible hand that rules America and a large sum of the world by controlling the capitalist class and now it is leading the nation America on a very much anti-democracy path. No matter who got elected to what office, the "professionals" from the council will in the end be the one drafting out policy proposals, debating over the context, develop consensus, then leading up to the implementation of almost all nation's key strategic policies for the United States.(Shoup)

There are two type of people who are involved with CFR, the richest and the smartest. One portion of the organization are made up by young professionals, those are the ones that the capitalist see potential in, some of them might not have much fortune in their hand from the start, but in different ways they have all shown unavoidable signs to be extraordinary someday.The other portion of the organization is made up by already successful people from the capitalist class itself, they are senior politicians, bankers, major company owners, and those are the ones making the final decisions on everything.

Though no individual in this world has the same desire, all the people who became a member of the CFR, regardless the background they came from, the industry they are in, the type of job they are having, or even their gender and sexuality, has the same interest in mind, and it is the interest of their class as a whole. Together they ran this country under their thumb 
by making laws and changing regulations that favors their operations, while reshaping the very own definition of democracy as see fit.

\subsection{Why is CFR related to Social Class Leaping}

When we are talking about young successful professionals that were being recruited by the CFR, the bar for entrance is exceedingly higher than any other social club you might seen. They have to be in between the age of 30 to 36, and they are mostly likely graduates from elite universities with an area of expertise in different discipline; With proper training and job replacement (mostly by commendation from other members) from the CRF and later on they will be groomed to be leaders in their field or even for the whole nation. For them, by using their knowledge they gained a edge comparing to people from their own world, then the CFR will serve as a bridge - way to make the leap from one social class to another and finally becoming a part of the capitalist class, then the trend continues on.

Bill Clinton was one of the most famous one among them all, he was born into a working class family in Hope Arkansan, attended Georgetown University,University College, Oxford, and Yale Law School in early days of his life, joined CFR then later on became the governor for Arkansan then the 42th president of the United State.

For many just have Bill Clinton, their family can not offer them any comparative advantage in a world that is controlled by power and money, so their only option into the capitalist world is by referral from member in that class, and CFR as the most powerful organization in the world is filled with that kind of resource. For people that came from a less privilege background, a membership at the CFR is like getting you hands on the ticket to a new world, it is almost guaranteed for a change in their social class and status.

\section{Why it is Almost Impossible to Join the CFR by Diligence Only}

According to statistic from 2018, there were approximately 19.6 million college students enrolled with around 14.5 million in public colleges and 5.1 million enrolled in private colleges. Every year around 280,000 students apply to the Ivy League schools and only around $8 \%$ can get in, making up to a approximate of 28,000 enrolling every year. Counting in all undergraduate and professional students from the Ivy league school, plus those from other elite universities such as MIT, CIT and Stanford, there are around 250,000 students enrolled in school right now that are can be considered quantifiable to the elite school standard for the CFR. Majority of those student are hard working students that probably were top of their class or even school district before entering college.

Though the competitiveness for the Ivy League schools is already brutal, it can still be seems as nothing in comparison to the selective of clubs such as CFR. Take Bill Clinton for example, before he joined CFR, he was a recipient of the Rhodes Scholarship. The Rhodes Scholarships are the oldest and most celebrated international fellowship awards in the world, and the selection process is beyond harsh. Each year, only 32 students from the United States 
6-8 August 2021

Budapest, Hungary

are selected to be Rhodes Scholars after going through a decentralized process, representing the 50 states, the District of Columbia, and the U.S. territories.(The Rhodes Scholarships) On top of that, Billion Clinton was also a member of Mensa, which is a origination for people with IQ at or above the 98th percentile on certain standardized IQ, currently the youngest Mensa member is Muhammad Haryz Nadzim who join the club after scoring 142 on his IQ test, and a above 145 in IQ is considered "genius or near genius" world wide. There are currently around 50,000 Mensa members in United State, while the country's population is estimated at 328.2 million. Even if anyone can manage to work 24 hours per day, there is still certain thing that they can not work on, such like nature born intelligence.

\section{Continuance in Wealth Gap in United States}

In 2007 the richest $1 \%$ of the American population owned $35 \%$ of the country's total wealth, and the next $19 \%$ owned $51 \%$. the remaining bottom $80 \%$ of the population only made up to $14 \%$ of the national wealth. In 2011, financial inequality continue to grow and inequality became more distinctive, top $1 \%$ of the population's wealth grown to a $43 \%$ and the next $19 \%$ of Americans owning remind at $50 \%$ leaving the bottom $80 \%$ with $7 \%$ (Jacobs). Moreover, numbers from a different resources showing during the second quarter of 2020, Number shows that the net wealth in the United States held by the top 10 percent 69 percent with a slight increase from the quarter before, this figure was at 60.5 percent in 1990. (Shown in figure.2 )

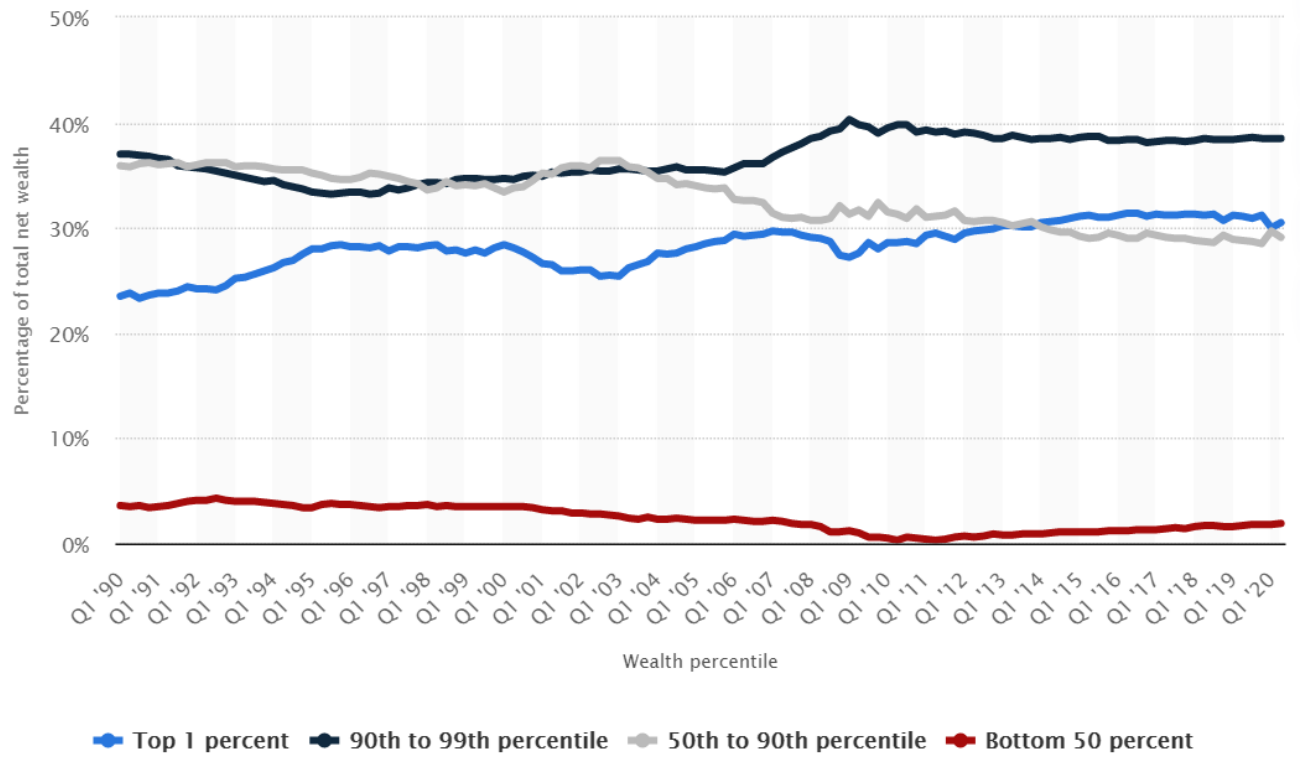

Figure 2. Wealth percentile from $1990-2020$ 
While most people are looking at the differences in wealth gap between the upper and lower class, middle class is also struggling with their financial growth while the upper class continues to consume most of the profit from production. Over a 48 year time period, research statistic from the Pew Research Center stated from 1970 to 2018, the median middle-class income increased from $\$ 58,100$ to $\$ 86,600$ with a gain of $49 \%$ is considerably less than the $64 \%$ increase for upper-income households, whose median income increased from $\$ 126,100$ in 1970 to $\$ 207,400$ in 2018(Schaeffer). In 2014 Harvard business school conducted a study on wealth inequality, after seeing the result the university declared that the growing disparity between the capitalist class and the lower and middle classes is no longer sustained at a reasonable level.

\section{What are Options Left for Ordinary People}

\section{1 professional-managerial class}

The term professional-managerial class is a hypothesis created by John and Barbara Ehrenreich in 1970, it is a social class within capitalism and in between the working class and the capitalist class, people from the professional- managerial class controls production processes through superior management skills, in ways they are considered neither proletarian (labor) nor bourgeois(owner).

This group of people normally exist within middle classes, by receiving extensive training and education typically through business qualifications and university degrees, they would possess certain rare skills then be hired by the capitalist class to join their productions. Normally those people would work in fields such as academics, teachers ,lawyers, doctors, engineers, high end designer,managers,middle

-level administrators and so on. Because of their specific skills, they were less likely to be replaced comparing to other working class people, in return the capitalist class would mostly likely to reward them with better benefit in order to maintain their long term employment. That being said, most of the professional-managerial class tends to have a higher incomes level above the average on a national income level scale.

Professional-managerial class is a social class where people from middle and working class can move up to by attending school, but is also the a ceiling for most people without nature born wealth and connections. Though by proper means of wealth accumulation and finance, few people from the professional-managerial class can ended up in capitalist class later on in life, a lawyer become the head of a world class law firm, a banker running his own hedge fund or a doctor turn in to a CEO for a big pharmaceutical company can all be viable examples in this case.

\subsection{Trade schools}


Though most of people would love to obtain a nine to five job in a nice office with a city or ocean view versus digging holes at a construction site sweaty all day long, there are still big sum of people living without the privilege to go to college.In most case those are kids coming from lower working class, and an increasing level in tuition can be a deal killer for most of them.In this case, trade schools can be one of the best alternative for college education.According to a Rutgers University study, trade schools are now seeing their job placement rates close to 100 percent, whereas employment for college students on average is only near $50 \%$. There is also an incentive for money, an average public school's instate tuition is near 20,000 dollars a year where trade school cost less than 5,000 dollars to complete; since 2009, college graduates have earned an average starting income of $\$ 27,000$ versus $\$ 42,000$ for trade school graduates. So if you were born into a less fortunate financial situation than others, trade school might be a great solution for you to gain a reasonable income and make a leap in social class. Because while other students were suffering from the the risk of employment burden of student loan, trade school graduates are mostly likely to start their life with a new job debt free.

\subsection{Sports, Art, Music and Other Specialties}

At this point everyone probably heard stories about how someone walking on the street one day got selected by talent scout, next thing you know they are hot and famous in Hollywood; the boy who posted a video of him singing on YouTube overnight became the next pop icon with millions of fans through out the world(The real life story of Justin Biber);Olympic winner are worldwide more worshiped than scientist and NFL players now sometimes seem to have a higher social status than God in the United State, Seattle Seahawks quarterback Russell Wilson made \$79 million in 2019 is now NFL's highest-paid player. Those type of success sometimes can be achieved without money or connection, lots of high achievers from those fields came from relatively disadvantaged personal background and is now standing on top of the world. Though all the success stories might sound tempting, for most people the chance of making it is no more than winning five million dollar lottery.

\section{Conclusion}

With only few cases of exceptions, mostly people living within a society like to think everyone has a common interest regardless of their gender, age, income level or personal habits, under that assumption, everyone is expected to live similarly and being offered same opportunists in life with diversity due to personal decision only. In reality, in a class based society,the ruling class will inevitably gains control over almost everything of importance in order to maintain their leadership of such society as whole, and the working class will be left with no other choice but to obey the rules which those who are in charge made. Present day democracy is just another way the capitalists made up to maintain control over their labors, by giving the public the false sensation that they are in charge of their own future, the ruling class successfully made the public less aggressive and easy to manipulate. 
6-8 August 2021

Budapest, Hungary

Due to the very nature of the ruling class, the only way a they can maintain their status is by making sure that their wealth is well preserved so their power can be inherited. For a class like that, minimum changes in personnel change is good mobility for the entire class. So it is very unlikely for anyone to enter a ruling class by simple working hard, democracy will always be rigged to serve the ruling, and diligence is nothing but a hypocrisy in term of achieving social class leaping and moving up the ladder.

\section{Reference}

Austin, Alana (January 7, 2019). "Josh Hawley, country's youngest Senator, takes place on Capitol Hill". graydc.com. Archived from the original on June 14, 2020. Retrieved January 4, 2020.

America's wealth gap 'unsustainable,' may worsen: Harvard study. Reuters, September 8, 2014.

Bureau of Labor Statistics. "Unemployment Rate NOVEMBER 2020." Bureau of Labor Statistics, 4 Dec. 2020, www.bls.gov/news.release/pdf/empsit.pdf.

Ehrenreich, John; Barbara Ehrenreich (1979). Pat Walker (ed.). Between Labor and Capital (1st ed.). Boston: South End Press. ISBN 0-89608-037-4.

Lahtinen, Hannu, et al. "Social Class and the Risk of Unemployment: Trends, Gender Differences and the Contribution of Education." Acta Sociologica, vol. 63, no. 3, Aug. 2020, pp. 303-321,

Occupy Wall Street And The Rhetoric of Equality Forbes November 1, 2011 by Deborah L. Jacobs

Parkin, F. Marx's Theory of History: A Bourgeois Critique. New York: Columbia University Press, 1979.

"The Rhodes Scholarships." Rhodes Trust, Office of the American Secretary, 21 Nov. 2020, www.rhodeshouse.ox.ac.uk/office-of-the-american-secretary.

Sjoberg, Gideon. “Are Social Classes in America Becoming More Rigid?” American

Sociological Review, vol. 16, no. 6, 1951, pp. 775-783. JSTOR, www.jstor.org/stable/2087504. Accessed 20 Dec. 2020.

Schaeffer, Katherine. "6 Facts about Economic Inequality in the U.S." Pew Research Center, 7 Feb.

2020,www.pewresearch.org/fact-tank/2020/02/07/6-facts-about-economic-inequality-in-t he-u-s.

Stack, Liam (July 13, 2018). "Republicans Had a Plan for Josh Hawley in Missouri. He's Working on It". The New York Times. Archived from the original on April 12, 2019. 
6-8 August 2021

Budapest, Hungary

Retrieved September 22, 2020.

Shoup, Lawrence H. \& Minter, William (1977). Imperial Brain Trust: The Council on Foreign Relations and United States Foreign Policy. Monthly Review Press.

Shoup, Laurence. Wall Street's Think Tank: The Council on Foreign Relations and the Empire of Neoliberal Geopolitics, 1976-2014. New, Monthly Review Press, 2019.

Stanger, Melissa. "Students Should Reconsider College As The Best Option After High School.” Business Insider, 16 .Dec.2012.

www.businessinsider.com/alternatives-to-college-trade-school-unemployment-2012-10 international $=$ true $\& \mathrm{r}=\mathrm{US} \& \mathrm{IR}=\mathrm{T}$. 